\title{
Effectiveness of Self Management in Reducing Truancy Behavior of High School Students in Bandar Lampung
}

\author{
Hardiyansyah Masya, Badrul Kamil \\ Universitas Islam Negeri Raden Intan Lampung \\ hardiyansyah.masya@radenintan.ac.id
}

Submitted: 2019-03-17, Revised: 2019-03-17, Accepted: 2019-06-25

\begin{abstract}
The phenomenon of disciplinary problems of the student is still happen. Discipline behavior is a behavior that demonstrates obedience and compliance which requires students to comply with established regulations. One of the most frequent disciplinary violations is leaving school without permission. Several factors that influence students to break discipline are environmental factors. Therefore, it needs proper handling in overcoming discipline problems of students. one technique that can be used in overcoming disciplinary problems, namely self-management. In the use of self management techniques to overcome undisciplined behavior students are directed to modify environmental aspects that can influence the emergence of undisciplined behavior.

Keywords: Self Management; Truancy Behavior
\end{abstract}

\section{Introduction}

Education is one of the efforts that can be done to help students develop their abilities and talents optimally so that the goals can be achieved. According to law number 20 of the national education system, states that "education is a conscious and planned effort to create a learning atmosphere and learning process so that students actively develop their potential to have spiritual strength, self-control, personality, intelligence, noble character, and the skills needed by them, society, nation and state ".

One of the facilities in education is teaching and learning activities that occur in schools. To support the effective learning process, it is necessary to activate the teacher and students in the learning process. If one is not actively involved, the learning process cannot run effectively. This is in line with Walgito's opinion (in Kadek, 2013) several factors that must be considered in learning are physical factors and psychological factors, which include motives, interests, concentration of attention, balance, personality, self-evidence, selfdiscipline, integration and memory.

Based on this fact, it can be seen that the presence of core components in the learning process is important in the learning process. However, not all students follow the rules and regulations set by the school. There are students who are not present at school hours due to various reasons. According to the results of research conducted at one of the high schools in Bandar Lampung (2018) out of 60 students 10 students had skipped school. Some reasons that make students leave school hours without permission are, $11.5 \%$ of students feel the teacher is boring in providing learning, $20.6 \%$ of students receive less attention from teachers, $27.2 \%$ are afraid to enter because they do not make assignments, $25,1 \%$ is affected by friends, $6 \%$ do not like the attitude of the teacher. Signing with this, based on the results of Apsari (2017) research at Public Junior High School 5 Bandar Lampung, the number of students who play truant every day reaches 4 students.

The results of other studies say some violations of school discipline are the percentage of students not enrolled / negligent at $0.13 \%$, students over 10 minutes late in 32 cases, and leaving unauthorized lessons for 16 cases. Whereas in the even semester, the percentage of students not enrolled in school without information is as much as $0.09 \%$, students over 10 minutes late as many as 31 cases and skipping and leaving unauthorized lessons as many as 20 cases (Joko Sumanto in Yohana, 2012). 
Based on data from studies that have been conducted in several schools, it appears that truant problems still occur frequently in students at school. To respond to the problem of blunting behavior that occurs it is necessary to do the right intervention. This is because, if truant behavior is not immediately given treatment, it will have a negative impact on students, such as not going up to class, being excluded from school, poor test scores, lagging in lessons, failing exams, decreasing learning achievement and affecting students another for ditching.

Educators in this case counseling teachers have a very important role in overcoming truancy behavior of students. This can be seen from one of the functions of counseling that is helping students / counselees who have problems so they can correct mistakes in thinking, feeling, willing, and acting. Students can act in accordance with the applicable norms and conditions in the environment in this case the school environment.

One approach in counseling that can be done to reduce truancy behavior is the behavior approach. Behavior approach is an approach to change from behavior. In the behavior approach there are several techniques, one of which is the self management technique. According to Komalasari, Wahyuni, and Karsih (in Amaliyah et al. 2018) selfmanagement is a procedure in which individuals regulate their own behavior. Looking at the use and purpose of group counseling and the technique of self-management, it is expected to reduce truant behavior in students at school.

Self management technique is one technique that can help students to manage themselves. The form of self-management in the technique of self management with environmental settings to facilitate the implementation of self-management (Gunarsa, 2014: 191). In the technical self-management counseling teacher role as the originator of ideas, facilitators who help design the program as well as motivators for counselees. Expected to be able to achieve desired behavioral changes can also develop the ability to manage themselves, so that it will affect the decrease in truancy behavior of students.

\section{Research Methods}

This study uses library research by utililizing the data or materials needed ini completing the research originating from the library ini the form of books, encyclopedias, dictionaries, journals, documents, magazines and so forth.

\section{Result and Discussion}

Self Management

To create students who are responsible for learning, in this case it can be done with a behavioral approach, where the behavioral approach is an approach to change from behavior, which holds that all behaviors are learned. In the behavior approach there are several techniques, one of which is technique self management. Self management is a behavior change strategy that in the process of the individual directs his own behavior with a technique or therapeutic (Hariningtyas, 2018). The use of this technique is based on the frequency of individuals failing to achieve goals due to lack of skills (Corey, 1995: 431). Based on this, technical self management can help students have skills in self-control in behavior. In individual self management techniques are asked to set their own behavior, and counselors only serve as facilitators in directing individuals to regulate their behavior (Gantina, 2011: 180).

Self management technique is a process of behavior change in which the counselee is responsible for directing his own behavior, starting from the planning carried out punishment and rewards that will be obtained when the counselee succeeds and fails to carry out the expected behavior changes. 
The purpose of self-management techniques is that students can manage their thoughts, feelings and actions so that students can behave in accordance with applicable provisions and values. In self-management techniques students and counseling teachers determine the goals they want to achieve together. Hartono (2015: 125) self management refers to the hope that counselees can be more active in the process of therapy. Cormier \& Cormier in Sutijono \& Soedarmadji states that this activation is shown to regulate or manipulate the environment in accordance with the behavior that will be formed.

To realize these goals, there are several components that individuals make in self management, namely, determining target behavior, monitoring the behavior, selecting procedures to be implemented, implementing the procedure, and evaluating the effectiveness of the procedure (Apsari, 2017). The purpose of self-management techniques for eliminate the factors that influence the emergence of behavior that will be made changes in this case namely truant behavior. The environmental arrangements include: a. change the physical environment so that undesirable behavior is difficult and impossible. for example people who like to "snack" regulate the environment so that food is available that provokes the desire to "snack"; b. change the social environment so that the social environment controls student behavior; c. change the environment or habits so that they become undesirable behavior can only be done at certain times and places (Komalasari, 2011: 180).

The steps taken in the technique of self management (Nursalim, 2013: 153), namely: 1) Self-Monitoring According to Cormier, the individual process observes and records something about himself and his interactions with the environment. Self monitor is used to assess problems, because observational data can explain the truth or changes in students' verbal reports about problematic behavior. The stages in Self-Monitoring are:

a) Rational Contains objectives and overview (brief description) of strategy procedures

b) Determination of the observed response Select the response target to be monitored (type of response, strength / valence response, number of responses

c) Record response

1) When taking notes / timings

2) Take notes before the appearance of behavior

used to reduce response. Record after appearance of behavior

used to add a response

3) Take notes immeiately

4) Note when there is no other response that is annoying

note taker / planner

a) Record method

1) Calculate frequency

2) Measuring the length

3) Record continuously / continuously

d) Make a map or graph of the amount of acquisition

recorded daily life

e) Showing data to get environmental support

f) Data analysis

5) Stimulus-control is the preparation / planning of predetermined environmental conditions, which makes the implementation of certain behaviors. Environmental conditions function as antecedents of a particular response. In other words, antecedents are a stimulus for a particular response.

6) Self-Reward is used to strengthen or to increase the expected or intended response. Self reward functions to accelerate behavior targets. The hope with the existence of self reward will provide confirmation of new behaviors that are starting to emerge. 
Truant behavior

Truant behavior is one form of undisciplined behavior that occurs in students. The truant behavior of students is marked by students leaving school hours without permission or knowledge of the school. According to Gunarsa (1981: 31) truant behavior is that students leave school hours or leave school before the lesson is over without permission from the school. Another opinion states that truant behavior in general can be interpreted as the behavior of students who do not enter school with inappropriate reasons or absences of students without clear reasons (Tutiona, Munir, Ratu, 2016). Sometimes students who play truant not only intentionally leave learning activities at school, but sometimes the desire to skip is suddenly when learning in school is ongoing. This happens when students feel saturated learning, or are having personal problems that result in a lack of enthusiasm in learning.

Students who indicated truant began to be seen from the symptoms that appeared. Prayitno and Amti (2004: 61) stated that behavior that began to be seen in students who indicated truant namely, days without going to school, not going to school without permission, often leaving at certain school hours, not re-entering after asking permission, entered schools change days, invite friends to come out on subjects that are not liked, ask permission to go out by pretending to be sick or other reasons, sending a permit does not enter with artificial reasons and does not enter class after recess.

The symptoms that appear are symptoms that are often seen in students, but not all students show the same symptoms in truant behavior. This can be seen from the different factors underlying the truant behavior of students. The factors underlying the truant behavior of students, namely, personal factors in this case, which is related to the point of view or individual beliefs in doing something, family factors in this case, namely lack of motivation and attention from parents, school factors in this case namely truant policies inconsistent, minimal interaction between parents of students and the school, unsportsmanlike teachers, and school assignments. Based on these factors, to anticipate the emergence of these factors it is necessary to deal with behavior change. According to Febriani (2017) human behavior is basically a behavior that is formed and studied, several ways in forming behavior, namely habits, the formation of behavior with understanding, the formation of behavior using a model. To form these behaviors, it can be done by using self management techniques because the self management technique can improve students' self control, so they can control antecedents (causes of problems) reduce the frequency of behavior, and rearrangement, so that expectations will reduce the appearance of bad behavior and better behavior will emerge.

\section{Conclusions and Suggestions}

The problem of ditching is one of the disciplinary problems that still occurs in students. Various factors that make students leave school hours such as, internal factors, lack of family attention, and school environment factors. If truant problems are not immediately addressed by the counseling teacher at the school it will have an impact on student learning outcomes such as students not going up to class, excluded from school, poor grades, lagging behind in lessons, failing exams, declining performance learning and can influence other students to play truant. Responding to these problems the counseling teacher can use a behavioral change approach, in the behavioral approach one technique that can be used to improve students' self-control is self management techniques. The hope is to use self-management techniques due to the 
emergence of problems (antecedent) can be controlled, reduce the frequency of occurrence of behavior, and restructuring, so that expectations will suppress the emergence of truant behavior and better behavior will emerge in this case, namely disciplinary behavior.

\section{References}

Amaliyah, Hamzah, Farial. (2018). Layanan Konseling Kelompok Dengan Teknik Self Management Untuk Mengurangi Perilaku Siswa Membolos Di SMPN 29 Banjarmasin Tahun Ajaran 2017/2018. Jurnal Bimbingan Konseling An-Nur. Retrieved From At Https://Ojs.Uniska-Bjm.Ac.Id/Index.Php/An-Nur/Article/View/1320.

Apsari, M.F. (2017). Konseling Individual Mengatasi Perilaku Membolos Menggunakan Pendekatan Behavioral Dengan Teknik Self-Management Pada Peserta Didik

Kelas VIII Di SMP Negeri 5 Bandar Lampung. Skripsi. Retrieved from athttp://repository.radenintan.ac.id/2345/

Corey, G. 1995. Teori dan Praktek Konseling dan Psikoterapi vol 4. Translated by: Drs. Mulyarto. Semarang: IKIP Semarang

Departemen Pendidikan Nasional. (2011). Undang-Undang SISDIKNAS Nomor 20 Tahun 2003. Jakarta: PT. Sinar Grafika.

Gunarsa, D Singgih. (2014). Konseling dan Psikoterapi. Jakarta: Penerbit Libri.

Hariningtyas, (2018). Pengaruh Konseling Behaviour Teknik Self Management Terhadap Perilaku Membolos Pada Siswa Kelas VIII SMP PGRI 1 Kediri. Jurnal SKTIP Pedagogis Vol (2), ISSN : 2599-073X. Retrieved from at: http:// simki.unpkediri.ac.id

Hartono, S.B. 2015. Psikologi Konseling. Jakarta: Kencana Prenanda Media Group.

Kadek, I,P, dkk, Efektifitas Konseling Behavioral Teknik Latihan Asertif Untuk Meningkatkan Prilaku Disiplin Belajar Siswa di kelas X SMA Laboratorium Undiksha, [online]: Jurnal Universitas Pendidikan Ganesha Tersedia: http://ejournal.ac.i d/index.php/JJBK/article/view/772/645

Komalasari. G dkk, (2011). Teori Dan Tekhnik Konseling. Jakarta barat: PT indeks.

Mili, A. (2017). Pengaruh Keterampilan Dasar Konseling Dengan Teknik Self Menegement Terhadap Perilaku Membolos Peserta Didik Di MTS Muhammadiyah. Skripsi. Retrieved from atrepository.radenintan.ac.id/1543/1/Skripsi_Full_HENI.pdf.

Nursalim, M. 2013 Strategi dan Intervensi Konseling. Jakarta: Akademia Permata.

Oktariana.Y, (2012). Program Bimbingan Pribadi Sosial Menggunakan Assertive Training Untuk Meningkatkan Disiplin Diri Siswa. Tesis, Retrieved from at: $\underline{\text { http://repository.upi.edu/8538/4/t_bp_1007011_chapter3.pdf }}$

Prayitno dan Erman Amti. (2004). Dasar dasar bimbingan dan konseling. Jakarta. Rieneka cipta.

Tutiona, M. Munir, A \& Ratu B. 2016. Upaya Mengurangi Perilaku Membolos Melalui Konseling Individual Dengan Teknik Behavior Contract Pada Siswa SMP Negeri 6 Palu. Jurnal Konseling dan Psikoedukasi Vo 1 (1). Retrieved from atrepository.ar-raniry.ac.id/5631/1/Zaitun\%20Jannah.pdf 
